годах этой ужасной войны. Основное внимание на занятиях уделяется не фактологической стороне, а анализу, сравнению, осмыслению, обоснованию своей точки зрения и т.д. Поэтому, этап знакомства с новой информацией занимает как можно меньше времени, большая же часть отводится самостоятельной работе учащихся, индивидуальному и групповому выполнению творческих заданий по изучаемой теме. Дети пишут проекты на военную тематику «Герой в моей семье», готовят презентацию «Мы помним, гордимся», ежегодно участвуют в метапредметной олимпиаде «Не прервется связь поколений».

Важную роль в обучении всегда играют картины, иллюстрации, портреты знаменитых людей нашего округа. (ТИНАО). Они несут в себе информацию, способствуют эмоциональному восприятию, учат видеть не только основное, но и второстепенное, обращать внимание на детали. При подготовке к урокам тесно сотрудничаю с учителями-филологами, учителями - географии.

Таким образом, каждый учитель истории и обществознания должен задумываться о духовно-нравственном развитии личности ребенка, необходимости формирования метапредметных, личностных, предметных результатов, без которых ученик не сможет быть успешным ни на любой ступени образования, ни в профессиональной деятельности. А каким будет урок - и состоит принципиальная новизна российского образования!

$$
* * *
$$

1. Алукаева А.П., Кочеваткина О.В. Введение регионального компонента в учебный процесс/ Учеб. пособие. - Саранск: Статуправление, 2005. - 83 с.

2. Шаповалов В.К. Этнокультурная направленность российского образования. - М.: Знание, 1997. $160 \mathrm{c}$.

3. Концепция федеральных государственных образовательных стандартов общего образования: Проект Российской академии образования / Под ред. А.М. Кондакова, А.А. Кузнецова [Текст]. M.: 2008 .

\title{
Попова С.B. \\ Русские обряды в диалоге культур народов Мордовии (на материале свадьбы в русских селениях)
}

ГБОУ Школа № 2075

(Россия, Москвы)

doi: $10.18411 / \mathrm{j}-08-2021-149$

\section{Аннотация}

В статье рассматривается свадебная обрядность - наиболее устойчивый компонент традиционно-бытовой культуры народов Мордовии. Именно в свадебном обряде прослеживаются пережитки архаических форм обычаев, верований, семейнобрачных отношений, сформировавшиеся в различные исторические эпохи.

Ключевые слова: Свадебная церемония; праздничная пища; курник обязательный атрибут свадебного стола, символизирующий плодородие молодой пары; разгонник - специальное кушанье, которым заканчивали свадебную церемонию; расстегай - открытый пирог, с начинкой из рыбы.

\section{Abstract}

The article examines wedding rituals - the most stable component of the traditional everyday culture of the people of Mordovia. In a wedding ceremony can be traced survivals of archaic forms of customs, beliefs, family relations, formed in different historical epochs.

Keywords: Wedding ceremony; festive food; kórnik - a mandatory attribute of the wedding table, symbolizing the fertility of the young couple; the booster is a special dish, which was finished a wedding ceremony; the pie is an open pie filled with fish. 
Традиционная русская свадьба на территории Мордовии представляла собой сложное переплетение правовых, социально-экономических, магических, нравственных и игровых действий и обрядов. В свадебной церемонии можно выделить три основных периода: предсвадебный, собственно свадебный и послесвадебный [1]. Традиционные обряды, проводимые на всех этапах свадьбы, были призваны обеспечить в дальнейшей жизни молодоженов их благополучие.

К предсвадебным обрядам относится сватовство, когда сваты делают официальное предложение. Сватовство, как обряд, широко распространено у русского населения Мордовии. Проведение этого обряда здесь аналогично обряду сватовства, описываемому исследователями в среде русских, проживающих в Поволжье, да и на территории всей России. Информаторами Мордовии отмечалось, что в сватовстве могли участвовать разные люди: отец, братья, иногда мать или специально выбранные сват и сваха [2].

Родители жениха засылали сватов в дом невесты. За сватовство отвечал старший в семье, а именно крестный отец или пожилые родственники, опытные в подобных делах, которые направлялись в дом невесты. Сваты объяснялись с отцом невесты, называли причину прихода в их дом, приговаривая: «Пришли в гости, не гостить, а пир подымать», «У вас товар, а у нас купец». Родители сначала советовались между собой, а потом звали дочь и спрашивали, нравится ли ей жених, при этом говорили: «Не нам с ним жить, а тебе» [3]. Так начиналось первое сватовство. Как правило, сватьям приходилось приезжать за окончательным ответом не один раз. Но случалось и так, что сама девушка не желала выходить замуж за предложенного парня, тогда отец отказывал во второй или третий раз и при этом отвечал: «Спасибо за честь, сват, но дочь отдавать не хотим» [4]. По словам информаторов, повсеместно, после полного согласия родителей, девушка начинала одаривать сватов рушниками и полотенцами в знак того, что она приняла их предложение. После чего сваты забирали подарки и каравай, испеченный в доме невесты по этому случаю, оставляя родителям в залог свой, а затем отправлялись в дом жениха с радостной вестью. С этого дня по общему согласию назначался день сговора (запоя), где обговаривался день свадьбы и происходило взаимное одаривание подарками, девушка все подарки дарила будущим родственникам: жениху - рубашку, его матери - отрез на платье, отцу - рубашку и полотенце, родственникам - платки и полотенца. Практически во всех селениях информаторы отмечали, что жених невесте чаще всего дарил кольцо, отрез на платье или обувь. На сватовстве на стол подавали вино, пиво, брагу, медовуху, пекли блины и хлеб из ржаной и пшеничной муки, рыбный пирог, студень, домашнюю лапшу, а также готовили щи, уху, кисель, мед [5]. Важное место среди элементов традиционной свадьбы занимала ритуальная свадебная пища, разновидность которой зависела от местных особенностей. На территории Мордовии состав свадебной пищи был чрезвычайно разнообразен. На свадебный стол традиционно подавались рыбники, курники, каши, яичница, блины, калачи, сочни, орешки, пельмени, всевозможные напитки, причем частично некоторые блюда были заимствованы у народов других национальностей [6].

За несколько недель до свадьбы происходило рукобитье - пирование у невесты. Пришедшие по приглашению хозяина садились за стол, накрытый скатертью. Подавались на тарелке пирог и соль. Отец невесты зажигал перед иконой свечу, все пришедшие вставали, а двери запирали на крючок, чтобы посторонний не мог сглазить. После молитвы сват или сватья через стол скрепляли правые руки сватов, и, взяв со стола пирог, обводили им руки сватов, трижды приговаривая: «Дело сделано, хлебом солью укреплено навеки. Аминь» [7]. Над руками пирог разламывали, а потом одну половину отдавали отцу жениха, а другую - отцу невесты (чья половина окажется больше - у того больше силы, счастья, здоровья, долголетия, богатства). Переломленный пирог хранился у невесты и жениха до свадьбы, а после венчания 
новобрачные должны были съесть его прежде всего; причем, жених - невестину половину, а невеста - женихову. Сватья при этом приговаривала: «Ешьте, милые, во славу Божью, во любовь вечную, бесконечную, яко же одно тесто в пироге, такожде и ваша плоть воедина до скончания века, неба и земли. Аминь» [8]. После разламывания пирога сваты садились за стол угощаться. Иногда рукобитье происходило у жениха. В таком случае отец жениха угощал отца, мать и родных невесты. К примеру, русское население Казанского Предволжья во время рукобитья благословляло жениха и невесту и проводило домашнее обручение. Для этого жениху и невесте подавали два стакана пива, куда они опускали кольца. Затем они трижды обменивались стаканами, выпивали пиво и надевали кольца: жених - купленное невестой, невеста - подаренное женихом. После угощения родителям и родственникам невесты подносили жениховы дары: мужчинам - в большинстве случаев пряники, женщинам - мыло. Все получающие подарки «молодились», т.е. целовали невесту и клали на тарелку, на которой та подносила вино и подарок, несколько монет. После окончательного согласия обе стороны начинали готовиться к свадьбе: резали животных, варили пиво, пекли хлеба [9].

Накануне свадьбы обязательно топили баню. В баню невесту сопровождали подруги, а караульщики охраняли ее. Обычно топил баню брат невесты, а воду носила сестра. В бане невеста мылась мылом, присланным женихом, угощала подруг гостинцами, которые передавал жених. По возвращению из бани невеста специальными причитаниями благодарила родителей за то, что они ее вырастили, вскормили, а также «за пар да баньку». Печь играла большую роль в свадебной обрядности. К примеру, в Дубенском районе сваха прикладывала к ней руки, чтобы переговоры о сватовстве закончились успешно. В Торбеевском районе у русских существовал обычай: когда молодых привозили из церкви, с песнями и шутками их клали на печку. У русских, проживающих в Кочкуровском и Рузаевском районах, сохранился обычай знакомить молодую с печью: она должна была показать умение ухватом.

В последний день или вечер перед свадьбой проходил девичник. К невесте собирались подруги, иногда приезжали родственники и знакомые из других селений. Во время девичника подруги помогали невесте приготовить подарки жениху, его родным, а также завершить подготовку приданого. Невеста прощалась с подругами, оплакивала свое девичество и исполняла вместе с подругами грустные песни. После песен и причитаний на девичник приезжал жених с товарищами, и вечер заканчивался ужином. На девичнике подруги невесты, в зависимости от местных обычаев, украшали брачную постель, оформляли основные свадебные блюда (каравай, свиную голову) огородным репьём, маленькой ёлочкой или березкой, пели песни и угощались. В некоторых районах на девичник приезжал и сам жених с товарищами. Так, например, в селе Три Озера Спасского уезда Пензенской губернии жених привозил самогон, а дружки - брагу. Когда они входили в дом, отец невесты ставил скамью поперек избы, сажал на нее приехавших и угощал их пивом и водкой. Жених угощал невесту, а она ему дарила носовой платочек.

В селе Горяйновка Октябрьского района, перед тем как отправить жениха к невесте, сваха надевала вывернутую наизнанку шубу, брала смесь хмеля и овса и ходила по двору, бросая хмель и овес на лошадей и людей. За ней шел сват и поливал брагой лошадей, стараясь при этом ударить сваху кнутом. Всё это делалось для того, чтобы отпугнуть злых духов от отъезжающих. После окончания положенных обрядов со звоном бубенцов выезжали со двора. Вслед за женихом уезжали и все гости.

Хлеб, как непременный атрибут свадьбы, известен во многих свадебных обрядах [10]. Так, отец и мать жениха встречали молодых на крыльце с хлебом и квасом, осыпали ячменём, пшеницей и хмелем; потом вводили их в избу и сажали за стол на первое место; за ними садились все гости. В селе Новосельцево Кочкуровского района 
молодых усаживали за стол на лавки, покрытые шубами или войлоком, приговаривая: «Шуба тепла и мохната - жить вам тепло и богато» [11].

По традиции свадебный ужин начинался с холодных блюд. В Ельниковском районе праздничным блюдом считался холодец, который готовили следующим образом: мясо с костями несколько часов варили на медленном огне, после остывания мясо отделяли от костей, мелко разрывали на кусочки, добавляли пряности, соль по вкусу, заливали бульоном и ставили в холодное место. Считали обязательным блюдом на свадебном столе рыбник, или по - другому, «расстегай» [12]. К примеру, в Теньгушевском районе начинка для расстегаев, как правило, готовилась из рыбы, но использовали также мясо, ливер, рис, грибы. Открытая середина пирога делала его как бы расстегнутым, отсюда и название «расстегай». Рыбники непременно пекли на «рукобитье» и ставили на предсвадебный стол в первую очередь. К предсвадебной трапезе в доме невесты не приступали до тех пор, пока стольник не раскроет рыбный пирог палочкой. Этот обычай назывался «проеданием невесты» [13].

Другое не менее распространенное свадебное блюдо - курник [14]. Курник пирог округлой формы, замешанный из пшеничной или полбенной муки на сливках, начиненный куриным мясом. В старину является куриное мясо, клали в пирог крупными кусками и даже вместе с костями. Как известно, курица считалась символом плодородия. В Торбеевском районе Мордовии по традиции курник выпекали и в доме жениха, и в доме невесты. Пирог жениха украшался человеческими фигурками из теста, а на курнике невесты вместо фигурок людей были цветы - символ женственности и красоты. Иногда внутрь курника запекали яйца в скорлупе, а сверху украшали курник куриной головкой из теста. В населенных пунктах Мордовии курники готовили и во время престольных праздников. В Темниковском районе их готовили с гречневой кашей [15].

У зажиточных хозяев свадебный стол ломился от изобилия мясных блюд. Характерным для русской кухни являлось приготовление крупных кусков мяса, зажаривание целыми тушками молочных поросят, домашней птицы. Из птицы жарили в основном кур, уток и гусей. Например, в Лаишевском и Мамадышевском уездах Казанской губернии в конце XIX в. был обычай подавать к свадебному столу живого гуся, украшенного тряпочками и бумажками [16].

По словам информатора О.Н. Корниенковой из с. Ханинеевка Ромодановского района, к концу застолья все поезжане напивались и наедались «до последней крайности», молодые же пили и ели весьма умеренно и сидели скромно, молча. Спустя некоторое время молодые выходили из-за стола и кланялись родителям в ноги, для того чтобы они их благословили. Интересный обряд зафиксирован у русских в Краснослободском районе, где к праздничному столу считалось обязательным в конце застолья подавать «разгонник» - кушанье, которое приготовлялось из муки и яиц с молоком. Только после этого блюда гости непременно расходились. Согласно традиции, на следующий день после свадьбы молодая обязательно пекла пирог. Им она потчевала гостей, и те по его вкусу судили об умении будущей хозяйки.

Свадебные гуляния старались разнообразить играми и забавами. Повсеместно распространенным игровым обычаем второго дня считалось «ряженье». Ряженые одевались в вывернутые шкуры: мужчины - в женскую одежду, женщины - в мужскую, а также в разных зверей, цыганами, солдатами и т.д. Они брали с собой предметы утвари, ходили по деревне с шумом и криками. Обычно торжества продолжались 3 дня, специальных обрядов не совершалось, а, как правило, повторялись различные развлечения, шли застолья с угощением, то в доме «молодого», то в доме «молодой». Но последний день празднования заканчивался обязательно в доме жениха.

Пища в свадебном церемониале выступала в нескольких ролях сразу: сакральная, праздничная, престижная. 
Таким образом, семейная обрядность русских в Мордовии, при сохранении своей национальной самобытности, на протяжении последнего времени подверглась определенной трансформации, что связано с изменением условий жизнеобеспечения в целом. Составной частью современной свадьбы становится торжественная регистрация брака. Религиозные аспекты свадебной обрядности, почти утраченные в советское время, вновь начали обретать былую значимость, что особенно относится к церковному венчанию. В целом же русская свадьба по сей день, не лишена этнического колорита, являясь делом не только вступающих в брак, но и всех родственников и друзей.

$$
\text { *** }
$$

1. Бусыгин Е.П., Зорин Н.В., Михайличенко Е.В. Общественный и семейный быт русского сельского населения Среднего Поволжья. Казань, 1973. С. 141.

2. Бромлей Ю.В. Современные проблемы этнографии: очерки теории и истории. М., 1981. С. 253.

3. Полевой материал автора (ПМА): Барыкина Зоя Ивановна, 1945 года рождения, д. Саввинские Выселки Торбеевского района, записи 2006 г.

4. ПМА: Гончаренко Таисия Кузьминична, 1935 года рождения, пос. Ромоданово Ромодановского района, записи 2006 г.

5. Добровольский Н.В. Свадебный обряд в Калужской губернии// Живая старина. Спб., 1902. С. 153.

6. Зорин Н.В. Русская свадьба в Среднем Поволжье. Казань, 1981. С. 156

7. ПМА: Канайкина Екатерина Матвеевна, 1923 года рождения, с. Пичуры Торбеевского района, записи 2007 г.

8. ПМА: Кипаев Михаил Алексеевич, 1946 года рождения, с. Айкино Большеберезниковского района. Записи 2008 г.

9. Коринфский А.А. Народная Русь: круглый год сказаний, поверий, обычаев и пословиц русского народа. М., 1994. С. 154.

10. Мартынова М.Ю. Мир традиций и межкультурное общение: в помощь школьному учителю. М., 2004. C. 101

11. Мокшин Н.Ф, Лузгин А.С. Мордовский народ в истории и культуре Российского государства / Н.Ф. Мокшин, А.С. Лузгин - Саранск: Мордовское книжное изд-во, 2012. С. 255.

12. Маркова С.С., Макаркин Н.П. Мордва: очерки по истории, этнографии и культуре мордовского народа/ С.С. Маркова, Н.П. Макаркин - Саранск: Мордов. кн. изд-во, 2012.С. 720.

13. Никонова Л.И., Юрченков В.А. Народы Мордовии: историко-этногр. исслед. / Л.И. Никонова, В.А. Юрченков, НИИ гуманитар. наук при Правительстве Республики Мордовия. - Саранск, 2012. С. $608+80$ л. вкл.

14. Терещенко А.В. Быт русского народа. М., 1999. ч. VII, С. 329.

15. ПМА: Учеватова Вера Васильевна, 1952 года рождения, с. Стандрово Теньгушевского района, записи 2006 г.

16. Щанкина Л.Н. Региональные особенности традиций татар-мишарей, проживающих в Мордовии: на примере поверий и обрядов, связанных с жилищем. // Этнокультурное образование: опыт и перспективы: материалы межригиональной научно-практической конференции. Саранск, 2007. C.56. 